\title{
Pain relief strategies during immunization
}

\author{
Estratégias para alivio da dor durante a imunização
}

Viviane Santos Fontes ${ }^{1}$, Caíque Jordan Nunes Ribeiroํ, Rodrigo Assis Neves Dantas ${ }^{1}$, Maria do Carmo de Oliveira Ribeiro ${ }^{1}$

DOI 10.5935/2595-0118.20180051

\section{ABSTRACT}

BACKGROUND AND OBJECTIVES: Vaccine is the most common source of pain in childhood, which can lead to the non-acceptance of immunization. Given that, healthcare professionals must use strategies to manage pain in their practice. The objective of this study was to analyze the non-pharmacological therapies used in clinical trials to manage pain during children's immunization.

CONTENTS: In this integrative review, we searched the LILACS, Medline, BDENF and Pubmed databases, using the keywords "Clinical trial," "Pain management" and "Immunization," with the Boolean operator AND. After searching and reading, eight articles were included in this review. The studies analyzed showed different techniques to manage pain, such as the use of movies, toys, facilitated position and parents' training.

CONCLUSION: The interventions studied proved to be beneficial to manage pain, and they can be performed by a professional or by the parents themselves, supporting the professionals in implementing it in their clinical practice.

Keywords: Child, Clinical trial, Immunization, Pain management.

\section{RESUMO}

JUSTIFICATIVA E OBJETIVOS: A vacina é o método mais comum de causa de dor na infância, podendo levar a não aceitação da imunização. Diante disso, os profissionais da saúde precisam usar estratégias para o manuseio da dor em sua prática. $\mathrm{O}$ objetivo deste estudo foi analisar as terapias não farmacológicas utilizadas em ensaios clínicos para o manuseio da dor durante a imunização de crianças.

CONTEÚDO: Nesta revisão integrativa, buscou-se artigos das bases de dados LILACS, Medline, BDENF e Pubmed, com o uso dos descritores "Ensaio clínico", "Manejo da dor" e "Imu-

1. Universidade Federal de Sergipe, Aracaju, SE, Brasil.

Submitted in March 01, 2018.

Accepted for publication on July 24, 2018.

Conflict of interests: none - Sponsoring sources: none.

Correspondence to:

Cidade Univ. Prof. José Aloísio de Campos

Av. Marechal Rondon, s/n - Jardim Rosa Elze

49100-000 São Cristóvão, SE, Brasil.

E-mail: vivianefontes00@hotmail.com

(C) Sociedade Brasileira para o Estudo da Dor nização", com o operador booleano $A N D$. Após busca e leitura, oito artigos foram incluídos nesta revisão. Os estudos analisados evidenciaram diferentes técnicas de manejo da dor como uso de filmes, brinquedos, posição facilitada e treinamento dos pais.

CONCLUSÃO: As intervençôes analisadas, demonstraram-se benéficas para o manejo da dor, podendo ser conduzidas por um profissional ou pelos próprios pais, amparando, dessa forma, os profissionais para sua implementação na prática clínica.

Descritores: Criança, Ensaio clínico, Imunização, Manuseio da dor.

\section{INTRODUCTION}

Vaccines are the most common source of iatrogenic pain in early childhood and are a considerable source of suffering for children subjected to this procedure, as also for their parents and those people responsible for the execution of the vaccination process ${ }^{1}$.

However, the pain and fear associated with the use of needles had been largely neglected until recently, especially considering these symptoms in early childhood. This means that health professionals need to include strategies for dealing with pain within clinical practice ${ }^{2}$.

The International Association for the Study of Pain (IASD) defines pain as "an unpleasant sensory and emotional experience associated with actual or potential tissue damage or described in terms of such damage". Also, pain is always subjective. Each individual person learns the application of the word through his or her own experiences regarding lesions, at the start of life ${ }^{3}$.

Fear of needles also helps to bring about a general non-acceptance of vaccination ${ }^{4}$. There are proven strategies to control anxiety and pain during the immunization process. Interventions are grouped thus: interventions during the procedure itself; physical interventions; and pharmacological interventions $s^{4,5}$.

However, little has been said about such strategies with the goal of analyzing the non-pharmacological therapies used in clinical trials for coping with the issue of pain during the immunization of children.

\section{CONTENTS}

This is a descriptive study, of the integrative review ilk, for the identification of academic works produced on the theme of dealing with pain during the immunization of children. The method comprises six stages: establishment of the problem (guidance for the project); selection of the sample; definition of the information to be extracted; analysis of results; presentation and discussion of results; and presentation of the revision ${ }^{6}$. Following the sequence of stages, we defined the core research issue as follows: which non-pharmacological therapies are used in clinical trials for handling pain during the immunization of children? 
The study was conducted based on the following databases: Latin American and Caribbean Health Sciences Literature (LILACS); Nursing Database (BDENF); and Pubmed, through free access on the websites of the Virtual Health Library (BVS) and the Department for Qualification of Higher-Level Personnel (CAPES-Brazil), through controlled descriptors as follows: "Ensaio clinico", "Manejo

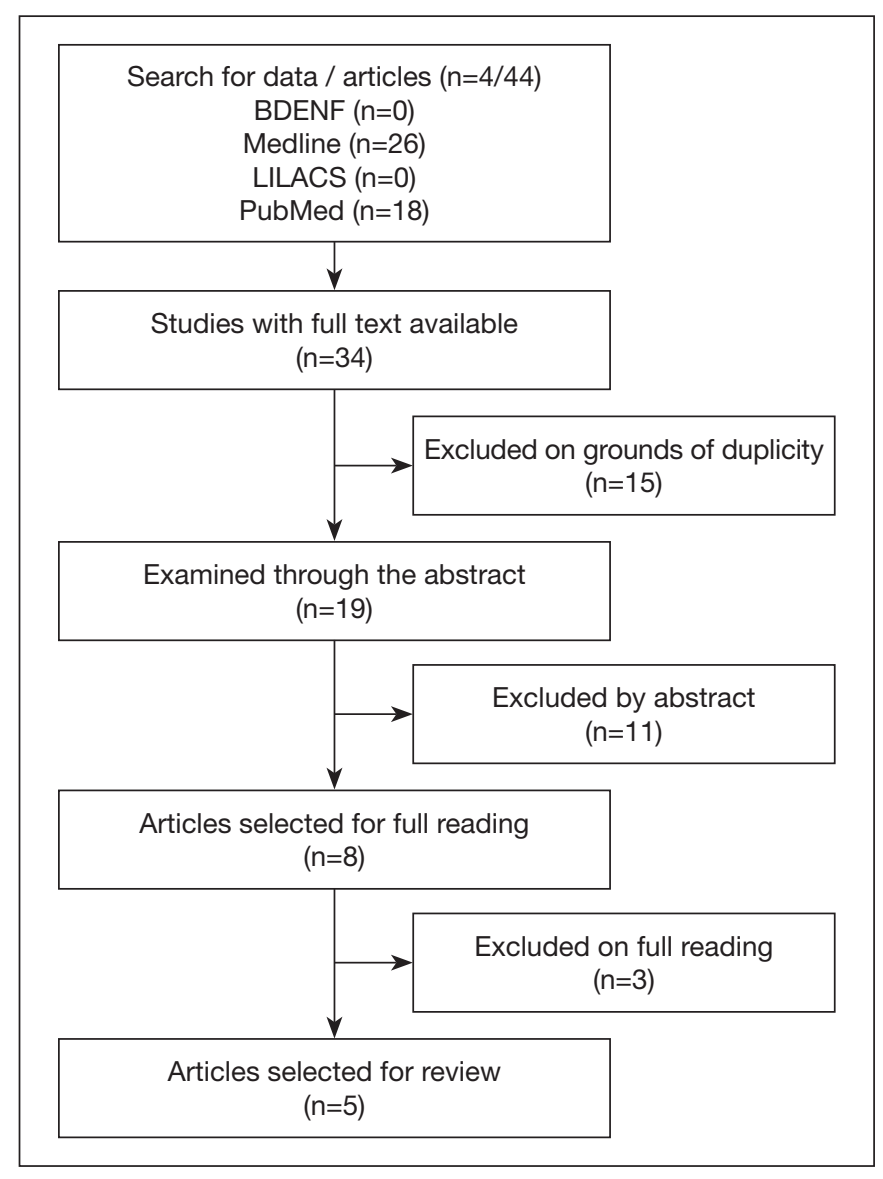

Figure 1. Flowchart for identification and selection of articles da dor" and "Imunização", as also their equivalents in the English language, with the Boolean operator $A N D$.

The collection of data took place in June 2017, involving the careful and critical reading of abstracts and then the full text of articles. The criteria applied were the following: 1) Inclusion - publications as from 2007; full text available; text in English, Portuguese or Spanish; research involving children aged 12 or under; use of non-pharmacological therapies; 2) Exclusion - research involving adults; use of animal models; with double indexing on databases. In this stage, we found 44 articles, as shown in figure 1 .

After selection, the articles were summarised and then documented based on the title, author, magazine, year and country of publication, and classified based on the level of scientific evidence ${ }^{7}$. Next, we conducted a critical analysis of the results through a descriptive synthesis of studies, showing the objectives, sample, method, strategy and main results. Later, these were discussed and presented.

The sample consisted of eight randomized clinical trials, found on the Medline and Pubmed databases and published between 2007 and 2015.

The studies were classified as showing level 2 of scientific evidence. With regard to language, all the studies were written in English. Five of the studies were carried out in Canada, two in Turkey, and one in the United States of America (USA). Table 1 below shows a synthesis of the articles shown in the study.

The pain caused by the vaccination may lead to changes in the future response to the painful phenomenon, including fear of needles. Even though there are different forms of intervention for pain relief, these are not always used in clinical practice ${ }^{1}$. In the light of this fact, when we analyze the different studies, we have seen evidence of different non-pharmacological strategies for dealing with pain while children are being vaccinated.

Parental involvement during immunization was brought up in most of the articles here considered (A1, A3, A4, and A5). The evidence shows that parents have shown great interest in learning the interventions for pain relief while children are being vaccinated ${ }^{8}$. The interventions with the parents involve an initial course of training, with guidance being given by the nursing team.

Table 1. Summaries of the studies included

\begin{tabular}{|c|c|c|c|c|}
\hline $\mathrm{N}^{\circ}$ & Goal/Sample & Method & Strategy & Main results \\
\hline $\mathrm{A} 1$ & $\begin{array}{l}\text { To appraise the impact } \\
\text { of the implementation } \\
\text { of pamphlet and video } \\
\text { at outpatient pediatric } \\
\text { clinics based inside } \\
\text { hospital units. } \\
\text { (160 parent-child } \\
\text { pairs). }\end{array}$ & $\begin{array}{l}\text { The pediatric outpatient } \\
\text { clinics were randomized } \\
\text { into two groups (the } \\
\text { control group - stan- } \\
\text { dard care, and interven- } \\
\text { tion group - review of } \\
\text { pamphlets and videos). } \\
\text { Materials: Pamphlet and } \\
\text { educational video. }\end{array}$ & $\begin{array}{l}\text { Control Group - the parents who attended } \\
\text { this clinic did not receive any kind of edu- } \\
\text { cational material. } \\
\text { Intervention Group - the parents of the chil- } \\
\text { dren who attended the clinic, as part of this } \\
\text { group, reviewed a pamphlet and a video } \\
\text { about dealing with pain during the proce- } \\
\text { dure of vaccination. } \\
\text { Two months after the first vaccination, they } \\
\text { returned, and, at that time, no attention was } \\
\text { attracted to either the pamphlets or the video. }\end{array}$ & $\begin{array}{l}\text { The parents who were in the interven- } \\
\text { tion group increased the use of inter- } \\
\text { ventions for the management of pain, } \\
\text { but there was no reduction in the level } \\
\text { of child pain within this group. }\end{array}$ \\
\hline $\mathrm{A} 2$ & $\begin{array}{l}\text { Appraise the level of } \\
\text { pain shown by new- } \\
\text { borns during vaccina- } \\
\text { tions against Hepatitis } \\
\mathrm{B} \text {, in the facilitated po- } \\
\text { sition and the classic } \\
\text { position for restraint. } \\
60 \text { newborns. }\end{array}$ & $\begin{array}{l}\text { The newborns were ran- } \\
\text { domly placed in one of } \\
\text { two groups (a control } \\
\text { group with standard care, } \\
\text { and an intervention group } \\
\text { using the facilitated posi- } \\
\text { tion). Materials: facilitat- } \\
\text { ed folding position. }\end{array}$ & $\begin{array}{l}\text { Control Group - vaccination car- } \\
\text { ried out in the upright position; } \\
\text { Intervention Group - vaccination carried } \\
\text { out in the facilitated folding position }\end{array}$ & $\begin{array}{l}\text { The pain intensity scores among the } \\
\text { lactating babies in the intervention } \\
\text { group were lower than in the control } \\
\text { group. } \\
\text { While } 50 \% \text { of the lactating babies in } \\
\text { the treatment group did not show pain, } \\
93.4 \% \text { of the lactating babies in the } \\
\text { control group showed intense pain. }\end{array}$ \\
\hline
\end{tabular}


Table 1. Summaries of the studies included - continuation

\begin{tabular}{|c|c|c|c|c|}
\hline $\mathrm{N}^{\circ}$ & Goal/Sample & Method & Strategy & Main results \\
\hline A3 & $\begin{array}{l}\text { Assess the usability } \\
\text { and efficacy, regard- } \\
\text { ing the acquisition of } \\
\text { knowledge, based on } \\
\text { the pamphlet and vid- } \\
\text { eo shown to parents of } \\
\text { newborns. } \\
33 \text { mothers, some of } \\
\text { whom accompanied by } \\
\text { their partners. }\end{array}$ & $\begin{array}{l}\text { Appraisal of usability of the } \\
\text { materials; individual and } \\
\text { group interviews; and knowl- } \\
\text { edge tests. } \\
\text { Materials - pamphlet and } \\
\text { video; a knowledge text with } \\
10 \text { true-false questions. }\end{array}$ & $\begin{array}{l}\text { Three groups of interviews were car- } \\
\text { ried out, divided into three distinct } \\
\text { phases: baseline (general questions } \\
\text { about pain experienced during infant } \\
\text { vaccination), review of the pamphlet, } \\
\text { and review of the video. } \\
\text { A moderator facilitated the discus- } \\
\text { sion using an interview outline and } \\
\text { then recorded what was said. } \\
\text { Next, an instrument was applied for } \\
\text { the appraisal of information regarding } \\
\text { health issues, and also a knowledge } \\
\text { test including } 10 \text { questions about the } \\
\text { understanding and adequacy of in- } \\
\text { formation, applied after the pamphlet } \\
\text { and the video were reviewed }\end{array}$ & $\begin{array}{l}\text { The parents were very receptive and } \\
\text { open to learning about strategies for } \\
\text { pain management. They also wanted ac- } \\
\text { cess to educational tools and reported } \\
\text { that the credibility of the information was } \\
\text { very important. } \\
\text { Most of the parents reported that they } \\
\text { understood all the information in the } \\
\text { pamphlet and on the video. } \\
\text { The mean number of correct answers } \\
\text { increased, from the base situation to the } \\
\text { post-pamphlet situation and from there } \\
\text { to the post-video situation. } \\
\text { All the parents reported that they planned } \\
\text { to take action, based on the information } \\
\text { included in the pamphlet and in the video. }\end{array}$ \\
\hline A4 & $\begin{array}{l}\text { Examine a computer- } \\
\text { ized programme for } \\
\text { parental training, "Bear } \\
\text { Essentials", to improve } \\
\text { parents' awareness and } \\
\text { to train them to help } \\
\text { to relieve their anguish } \\
\text { on the immunization } \\
\text { of preschool children. } \\
\text { ( } 90 \text { parent-child pairs) }\end{array}$ & $\begin{array}{l}\text { The parent-child pairs were } \\
\text { randomly distributed in three } \\
\text { groups (Control Group, with } \\
\text { standard care; Interven- } \\
\text { tion Group } 1 \text { - distraction; } \\
\text { and Intervention Group } 2 \\
- \text { training and distraction). } \\
\text { Materials: children's films; } \\
\text { programme for parental } \\
\text { training - "Bear Essentials." }\end{array}$ & $\begin{array}{l}\text { Control Group: no train- } \\
\text { ing or distraction of any kind; } \\
\text { Intervention Group } 1-\text { no training; } \\
\text { distraction with children's films; } \\
\text { Intervention Group } 2 \text { - Parental } \\
\text { training through the "Bear Essen- } \\
\text { tials" programme, and distraction } \\
\text { with children's films }\end{array}$ & $\begin{array}{l}\text { The parents subjected to training had } \\
\text { significantly higher scores than the oth- } \\
\text { ers, showing a better level of knowledge, } \\
\text { greater involvement, and encourage- } \\
\text { ment of distraction. } \\
\text { The children whose parents participated } \\
\text { in the training programme got more in- } \\
\text { volved in distractions and deep breath- } \\
\text { ing. On the other hand, no differences } \\
\text { were observed with regard to the chil- } \\
\text { dren's pain. }\end{array}$ \\
\hline A5 & $\begin{array}{l}\text { Provide more solid } \\
\text { conclusions about the } \\
\text { efficacy and the mech- } \\
\text { anisms of distraction, } \\
\text { as a way to control pain } \\
\text { during early childhood } \\
99 \text { children. }\end{array}$ & $\begin{array}{l}\text { The children were randomly } \\
\text { placed in three groups (a con- } \\
\text { trol group with standard care; } \\
\text { Intervention Group 1, with } \\
\text { distraction directed by the } \\
\text { research assistant, and Inter- } \\
\text { vention Group 2, with distrac- } \\
\text { tions directed by the parents). } \\
\text { Materials: toys. }\end{array}$ & $\begin{array}{l}\text { Control Group: the parents interact- } \\
\text { ed with the children, but without any } \\
\text { training or distraction of any kind; } \\
\text { Intervention Group } 1-\text { The par- } \\
\text { ents hold the child while the assis- } \\
\text { tant distracts the child using a toy; } \\
\text { Intervention Group } 2 \text { - The parents } \\
\text { hold the child and encourage the } \\
\text { use of the toy. }\end{array}$ & $\begin{array}{l}\text { The level of distraction was signifi- } \\
\text { cantly higher in the two intervention } \\
\text { groups, rather than the control group. } \\
\text { However, there was no difference in the } \\
\text { pain experienced by the children, be- } \\
\text { tween the two groups. }\end{array}$ \\
\hline
\end{tabular}

Parents who received some kind of guidance or training manage to get involved in more techniques for distraction, encouragement, and promotion of tackling during the procedure ${ }^{9,10}$.

The use of an educational tool to guide parents was addressed in A3 and A4. Among the educational techniques, we highlight the use of pamphlets, videos, and even a computer programme containing basic information on the options available for pain management. The use of these techniques significantly increased the knowledge and the awareness of the parents, with regard to the intervention, and also the level of confidence for the execution thereof ${ }^{8}$.

Distraction techniques are very much used for pain management during the process of immunization, especially through the use of children's films and toys (A4 and A5). The use of films and toys brought an increase in tackling behavior among children and has contributed to promoting the strategy of tackling, among parents and among the nursing team ${ }^{9-11}$.

The techniques for child positioning, during the process of vaccination, have not been discussed at length in the articles included in this review. Only one of these articles (A2) addressed the use of the facilitated folded position for the immunization of newborns. The use of the facilitated position is simple, cheap, and non-invasive, and this contributes to pain relief due to vaccination, thereby making it easier to care for newborns ${ }^{12}$.

\section{CONCLUSION}

The analysis of the studies has addressed countless intervention strategies for pain relief during vaccination, whether led by a professional person or by the parents themselves. The different methods of intervention bring approaches based on distraction, especially through the use of toys and children's films.

The studies have also shown evidence of the importance of the participation of the parents during the procedure, after due training or use of an educational tool with pamphlets, videos or other educational programmes, and have shed light on the benefits of the facilitated position for newborns.

The knowledge obtained through this study has shown that the implementation of different techniques for pain relief has shown itself to be beneficial for the handling of pain among children of different ages, thereby being a form of support to the professional staff, for use in clinical practice.

\section{REFERENCES}

1. Taddio A, Chambers CT, Halperin SA, Ipp M, Lockett D, Rieder MJ, et al. Inadequate pain management during routine childhood immunizations: the nerve of it. Clin Ther. 2009;31(Suppl 2):S152-67.

2. McMurtry CM, Pillai Riddell R, Taddio A, Racine N, Asmundson GJ, Noel M, et 
al. Far from "just a poke: common painful needle procedures and the development of needle fear. Clin J Pain. 2015;31(10 Suppl):S3-11.

3. IASP. Classification of Chronic Pain. $2^{\text {nd }}$ ed. Merskey H, Bogduk N, editors. IASP Pain Terminology. Seattle: IASP Press; 1994. 240p.

4. Taddio A, Ipp M, Thivakaran S, Jamal A, Parikh C, Smart S, et al. Survey of the prevalence of immunization non-compliance due to needle fears in children and adults. Vaccine. 2012;30(32):4807-12.

5. Taddio A, McMurtry CM, Shah V, Riddell RP, Chambers CT, Noel M, et al. Reducing pain during vaccine injections: clinical practice guideline. CMAJ. 2015;187(13):975-82.

6. Ursi ES. Prevenção de lesôes de pele no perioperatório: revisão integrativa da literatura [Internet]. [Ribeirão Preto]: Universidade de São Paulo, Escola de Enfermagem de Ribeirão Preto; 2005. Available from: http://www.teses.usp.br/teses/disponiveis/22/22132/tde-18072005-095456/pt-br.php.

7. OCEBM Levels of Evidence Working Group, Durieux N, Pasleau F, Howick J. The Oxford 2011 Levels of Evidence. Group [Internet]. 2011;1(version):5653. Available from: http://www.cebm.net/index.aspx?o=1025.
8. Taddio A, Shah V, Leung E, Wang J, Parikh C, Smart S, et al. Knowledge translation of the HELPinKIDS clinical practice guideline for managing childhood vaccination pain: usability and knowledge uptake of educational materials directed to new parents. BMC Pediatr. 2013;13:23.

9. Cohen LL, Rodrigues NP, Lim CS, Bearden DJ, Welkom JS, Joffe NE, et al. Automated parent-training for preschooler immunization pain relief: a randomized controlled trial. J Pediatr Psychol. 2015;40(5):526-34.

10. Cohen LL, Blount RL, Panopoulos G. Nurse coaching and cartoon distraction: an effective and practical intervention to reduce child, parent, and nurse distress during immunizations. J Pediatr Psychol. 1997;22(3):355-70.

11. Hillgrove-Stuart J, Pillai Riddell R, Horton R, Creenberg S. Toy-mediated distraction clarifying the role of distraction agent and preneedle distress in toddlers. Pain Res Manag. 2013;18(4):197-202.

12. Kucukoglu S, Kurt S, Aytekin A. The effect of the facilitated tucking position in reducing vaccination-induced pain in newborns. Ital J Pediatr. 2015;41:61. 